\title{
Physico-chemical properties, fatty acid and mineral content of some walnuts (Juglans regia L.) types
}

\author{
Mehmet Musa Özcan ${ }^{1 *}$, Cesari İman², Derya Arslan ${ }^{1}$ \\ ${ }^{1}$ Department of Soil Science, Faculty of Agriculture, University of Selçuk, Konya, Turkey; ${ }^{*}$ Corresponding Author: mozcan@selcuk.edu.tr \\ ${ }^{2}$ Food Engineering, Kırşehir, Turkey
}

Received 12 June 2010; revised 28 June 2010; accepted 13 July 2010.

\begin{abstract}
Some physical and chemical properties, mineral content and fatty acid compositions of kernel and oils of several walnut types (Büyük Oba, Kaman-2, Kaman-5) were determined. The oil yields from these kernels changed between $61.4 \%$ to $72.8 \%$. The crude fibre contents of kernels ranged between $3.77 \%$ and $3.80 \%$. In addition, crude protein contents of kernels ranged between $7.05 \%$ and $8.10 \%$. While the peroxide values of kernel oils change between $3.18 \mathrm{meq} /$ $\mathrm{Kg}$ and $3.53 \mathrm{meq} / \mathrm{Kg}$, acidity values ranged between $0.35 \%$ and $0.56 \%$. The main fatty acids of walnut kernel oils were oleic, linoleic, linolenic and palmitic acids. Linoleic acid contents of kernel oils varied between $49.7 \%$ and $55.5 \%$. On the other hand, oleic acid contents ranged between $20.5 \%$ and $26.4 \%$. As a result, the present study showed the walnut kernels of the researched species of walnut kernels from Turkey are a potential source of valuable oil which might be used for edible and other industrial applications.
\end{abstract}

Keywords: Walnut; Kernel; Oil; Fatty Acid Composition; Mineral Contents

\section{INTRODUCTION}

Walnut (Juglans regia L) a member of Juglandaceae family is one of the finest nuts of temperate regions. It is the oldest cultivated fruit in the world and grown spontaneously almost all over Turkey. Fifty percent of production is consumed on- form and the remainder is marketed [1-3].

Ripe walnuts are mostly eaten as dessert nuts or used in cakes, desserts and confectionery of all kinds from ice cream to Baklava. The walnut plant has a high nutria- tional value and high quality wood. In turkey, walnut has a special value in Turkish foods and is very common in traditional Turkish foods [2]. Although walnuts are rich in fat, a diet supplemented with walnuts had a beneficial effect on blood lipids, lowering blood cholesterol and lowering the ratio of serum concentrations of low deroity lipoprotein: high density lipoprotein by $12 \%$ [4,5]. Oil contents of walnut kerrels can generally vary from 52 to $70 \%$ depending on the cultivar, location grown and irrigation rate $[2,3,6-8]$. Most nuts are rich in manounsaturated fat (oleic acid) while walnuts are also high in two polyunsaturated fatty acids linoleic acid and $\alpha$-linolenic acids. The major fatty acids found in walnut oil are oleic, linoleic and linolenic acids $[3,5,8]$. The fatty acid profile of walnut oil varies between cultivars. It is important to a identify these differences in locally grown cultivars and to identify which fatty acids give the best nutritional qualities [8,9]. Some fruit seeds such as cherry, apricot, citrus and apple can be used as sources of oils. Some seed oils are already used for several purposes: blending with highly saturated edible oils to provide new oils with modified nutritional values as ingredients in paint and varnish formulations, surface coatings and oleo-chemicals, and as oils for cosmetic purposes [10].

The aim of this study was to determine their physical and chemical properties, mineral contents and fatty acid composition of some walnut types collected from Kırşehir province in Turkey.

\section{MATERIAL AND METHOD}

\subsection{Material}

The kernels of some walnut cultivars (Büyük Oba, Kaman-2, Kaman-5) were obtained by hand processing from walnuts growing in Kırşehir province of Turkey in August 2008. Kernels were kept in glass jars until analyses at refrigerator. In all stages of trials, dry and mature kernels have been used. 


\subsection{Physical Analyses}

Shelled weights of walnuts: It was used 25 unit walnut for each walnut variety. Each walnut was weighted separately, and average hulled fruit weights for each one were found.

Shelled diameters of walnuts: Mean diameter of each hulled walnut was measured by using electronic cumpas.

Yields of walnuts: Five walnut were used for yield analysis of each walnut. Yield was calculated as the percentage rate to the shelled walnut fruit of kernel weight.

Determination of dry matter: Air dried and ground walnut samples were waited in incubator calibrated to $105^{\circ} \mathrm{C}$ for $24 \mathrm{~h}$, and about $10 \mathrm{~g}$ samples from each dried walnut was weighted.

\subsection{Chemical Analyses}

The some chemical compositions (crude oil, crude protein, crude fiber, and crude ash, acidity, peroxide value, refractive index and saponification value) were analyses according to AOAC [11]. For oil analyses, each samples was homogenized and subjected to extraction for $6 \mathrm{~h}$ with petroleum ether (boiling range $30-60^{\circ} \mathrm{C}$ ) in a Soxhlet apparatus. The extracted oil was dried over anhydrous sodium sulphate and the solvent was removed under reduced pressure in a rotary film evaporator. Oil percentages were determined by weight difference. Ash was determined in a muffle furnace at $900^{\circ} \mathrm{C}$ for $8 \mathrm{~h}$ [11]. The nitrogen content estimated by the Kjeldahl method and was converted to protein content by using the conversion factor 6.25 .

\subsection{Determination of Fatty Acids}

Fatty acid composition for walnut kernel samples were determined using a modified fatty acid methyl ester method as described by Hış1 [12]. The oil was extracted three times for $2 \mathrm{~g}$ air-dried seed sample by homogenization with petrolium ether. The oil samples $(50-100 \mathrm{mg})$ were converted to its fatty acid methyl esters (FAME). The methyl esters esters of the fatty acids $(1 \mu \mathrm{l})$ were analysed in a gas chromotography (Shimadzu GC-2010) equipped with a flame ionising detector (FID), a fused silica capillary column $(60 \mathrm{~m} \times 0.25 \mathrm{~mm}$ i.d.; film thickness 0.20 mikrometere). It was operated under the following conditions: oven temperature program. $90^{\circ} \mathrm{C}$ for $7 \mathrm{~min}$. Raised to $240^{\circ} \mathrm{C}$ at a rate $5^{\circ} \mathrm{C} / \mathrm{min}$ and than kept at $240^{\circ} \mathrm{C}$ for $15 \mathrm{~min}$ ); injector and detector temperatures, 260 and $260^{\circ} \mathrm{C}$; respectively, carrier gas. nitrogen at flow rate of $1.51 \mathrm{ml} / \mathrm{min}$; split ratio $1 / 50 \mu \mathrm{l} / \mathrm{min}$.

A Standard fatty acid methyl ester mixture (Sigma Chemical Co.) was used to identify sample peaks. Commercial mixtures of fatty acid methyl esters were used as reference data for the relative retention times [13]. Quantitative analyses of the fatty acids were performed using the heptadecanoic acid methyl ester as internal standard. The results are mean values of three replicates.

\subsection{Determiation of Mineral Contents}

About $0.5 \mathrm{~g}$ of dried and walnut kernels were put into burning cup with $15 \mathrm{ml}$ of pure $\mathrm{NHO}_{3}$. The sample was incinerated in a MARS 5 microwave oven (CEM corporation Manufactura) at $200^{\circ} \mathrm{C}$. Distilled deionized water and ultrahigh-purity commercial acids were used to prepare all reagents, standards and walnut kernel samples. After digestion treatment, samples were filtrated through whatman No 42. The filtrates were collected in $50 \mathrm{ml}$ Erlenmayer flasks and analysed by ICP-AES (Varian). The mineral contents of the samples were quantified against standard solutions of known concentrations which were analysed concurrently [14].

Working conditions of ICP-AES:

Instrument: ICP-AES (Varian-Vista

RF Power: $0.7-1.5 \mathrm{kw}$ (1.2-1.3 kw for Axial)

Plasma gas flow rate (Ar): 10.5-15 L/min. (radial) 15 (axial)

Auxilary gas flow rate (Ar): 1.5

Viewing height: $5-12 \mathrm{~mm}$

Copy and reading time: $1-5 \mathrm{~s}(\max .60 \mathrm{~s})$

Copy time: $3 \mathrm{~s}$ (max. $100 \mathrm{~s}$ )

\subsection{Statistical Analyses}

Results of the research were analysed for statistical significance by analysis of variance [15]. This research was performed by three duplicates with a replicate.

\section{RESULTS AND DISCUSSION}

The physical and chemical properties of some walnut varieties (Büyük Oba, Kaman-2, Kaman-5) collected from Kurşehir province in Turkey are given in Table 1. The weight with hull, diameter, hull weight, kernel weight, yield, dry matter, crude fibre, crude ash, crude protein, crude oil, saponification, refraxtive index, acidity, peroxide value of walnut kernels were determined. According to variance analyses, important differences were found between physical properties and their weighs and kinds as statistical, $\mathrm{p}<0.01$ level.

The oil yields of kernels varied from 53\% (Büyük Oba and Kaman-5) to $60 \%$ (Kaman-2 cv) of the dry weight. The oil contents of kernels changed among the varieties to more than about $60 \%$ of each. However, because of economical value of the oil, these kernels could be used as potential sources of oils. Büyükoba cultivar had the highest oil $(72.87 \%)$ content, followed by Kaman-5 cv (72.13\%) and Kaman-2 cv (61.38\%). The 
Table 1. Some physical and chemical properties of walnut kernel and oils.

\begin{tabular}{|c|c|c|c|c|c|c|}
\hline \multirow{3}{*}{$\begin{array}{c}\text { Properties } \\
\text { Weight with shelled (g) }\end{array}$} & \multicolumn{6}{|c|}{ Walnut types } \\
\hline & \multicolumn{2}{|c|}{ Kaman-5 } & \multicolumn{2}{|c|}{ Büyük Oba } & \multicolumn{2}{|c|}{ Kaman-2 } \\
\hline & 12.96 & $\pm 1.00 \mathrm{~b}$ & 15.74 & $\pm 0.02 \mathrm{a}$ & 13.6326 & $\pm 0.03 \mathrm{~b}$ \\
\hline Diameter with shelled $(\mathrm{mm})$ & 36.72 & $\pm 1.22 \mathrm{~b}$ & 41.02 & $\pm 0.98 \mathrm{a}$ & 39.79 & $\pm 0.9 \mathrm{a}$ \\
\hline Shell weight (g) & 6.6882 & $\pm 0.01 \mathrm{a}$ & 7.7585 & $\pm 0.0005 \mathrm{a}$ & 4.3256 & $\pm 0.01 \mathrm{~b}$ \\
\hline Kernel weight (g) & 7.815 & \pm 0.005 & 8.9289 & \pm 0.02 & 6.5872 & \pm 0.0198 \\
\hline Yield (\%) & 53 & $\pm 0.4 \mathrm{~b}$ & 53 & $\pm 2 \mathrm{~b}$ & 60 & $\pm 2.5 \mathrm{a}$ \\
\hline Drt matter $(\%)$ & 99.58667 & \pm 0.015275 & 98.58333 & \pm 1.440498 & 99.58 & \pm 0.04359 \\
\hline Crude oil (\%) & 72.13 & \pm 4.681047 & 72.865 & \pm 8.619632 & 61.375 & \pm 10.3450 \\
\hline Peroxide value (meq $\mathrm{O}_{2} / \mathrm{kg}$ ) & 3.5294 & \pm 0.0004 & 3.1849 & \pm 0.0999 & 3.4482 & \pm 0.0103 \\
\hline Crude fiber (\%) & 3.90 & \pm 0.60 & 3.77 & \pm 0.32 & 3.87 & \pm 0.31 \\
\hline Acidity (\%) & 0.5628 & \pm 0.0101 & 0.35 & \pm 0.015 & 0.5575 & \pm 0.01015 \\
\hline Saponification value & 114.60 & $\pm 0.01 \mathrm{a}$ & 106.96 & $\pm 0.01 \mathrm{~b}$ & 102.09 & $\pm 1.00 \mathrm{c}$ \\
\hline Ash (\%) & 1.985 & \pm 0.431335 & 1.71 & \pm 0.028284 & 2.525 & \pm 1.15259 \\
\hline Crude Protein ${ }^{\mathrm{a}}(\%)$ & 8.10125 & \pm 0.055225 & 7.0489 & \pm 1.099834 & 7.24155 & \pm 1.878 \\
\hline Refractive index (nD20) & 1.535 & \pm 0.0005 & 1.534 & \pm 0.00005 & 1.537003 & \pm 0.0001 \\
\hline
\end{tabular}

${ }^{\mathrm{a}} \mathrm{N} \times 6.25$

crude fibre contents ranged between $3.77 \%$ (Kaman-5 cv) and $3.90 \%$ (Büyükoba). While crude ash contents changed between $1.99 \%$ (Kaman-5 cv) and 2.53\% (Kaman2 ), crude proteins of kernels ranged between $7.05 \%$ (Büyükoba cv) to $8.10 \%$ (Kaman-5 cv). In addition, kernel weights changed between $6.59 \mathrm{~g} / \mathrm{unit}$ (Kaman-2 and $8.93 \mathrm{~g} / \mathrm{unit}$ (Büyükoba cv). These results are comparable to data previously reported in the literature $[7,16]$. Nuts and oils intended to be cooked may require a low polyunsaturated fatty acid content [17].

Some physical and chemical properties of walnut kernels and oils are given in Table 1. According to variance analyses, differences between varieties to saponification values were found statistically important at the $p$ $<0.01$ level. While the peroxide values of kernel oils change between 3.18 (Büyükoba) and $3.53 \mathrm{meq} / \mathrm{Kg}$ (Kaman-5 cv), acidity values ranged between $0.35 \%$ (Büyükoba cv) and 0.56\% (Kaman-5 and Kaman-2). Refractive index was determined between 1.534 (Büyükoba) and 1.537 (Kaman-2 cv). In addition, saponification values of kernel oils were measured between 102.09 (Kaman-2 cv) and 114.60 (Kaman-5 cv). Differences among the values of walnut varieties can probably be because of growing conditions, climatic, environmental conditions and analytic conditions.

Fatty acid compositions of walnut kernel oils are given in Table 2. Results showed that the oils of all va-
Table 2. Fatty acid composition of walnut oils (\%).

\begin{tabular}{cccc}
\hline \multicolumn{3}{c}{ Walnut types } \\
\hline Fatty Acids & Kaman-5 & Büyük Oba & Kaman-2 \\
\hline $\begin{array}{c}\text { Palmitic } \\
(\text { C16:0) }\end{array}$ & 6.5 & 6.3 & 6.3 \\
$\begin{array}{c}\text { Stearic } \\
\text { C18:0) }\end{array}$ & 2.6 & 2.5 & 2.6 \\
$\begin{array}{c}\text { Oleic } \\
(\text { C:18:1) }\end{array}$ & 26.4 & 22.2 & 20.5 \\
$\begin{array}{c}\text { Linoleic } \\
(\text { C18:2) }\end{array}$ & 49.7 & 53.6 & 55.5 \\
$\begin{array}{c}\text { Linolenic } \\
(\text { C:18:3) }\end{array}$ & 14.3 & 14.5 & 14.8 \\
\hline
\end{tabular}

rieties used in this experiment had higher linoleic and oleic acid contents. Linoleic acid contents of kernel oils ranged between $49.7 \%$ (Kaman-5 cv) and 55.5\% (Kaman-2 cv). The proportions of the most abundant fatty acids (linoleic acid) of the kernel oils varied among different varieties. This proportion was also higher than that in other fruit seed oils; mahaleb (35.4\%), cherry laurel $(53.7 \%)$, date pit $(49.54 \%)$, walnut $(13.8-33.0 \%)$ $[8,18-20]$. Stearic and palmitic acids are the main saturated components in all walnut cultivars. Palmitic acid is differed in the different walnut cultivars. Its percentage was found between 6.3\% (Kaman-5) and 6.3\% (Büyükoba and Kaman-2). These results are in good agreement with 
in fatty acid composition for several walnut kernels $[2,3,5,6-8]$. Our results are similar in fatty acid composition when compared to the values in the literature.

Palmitic, stearic, oleic, linoleic and linolenic acid contents of walnut oil were established as $7.22 \%, 1.07 \%$, $28.51 \%, 52.46 \%$ and $10.50 \%$, respectively [221]. Özkan and Koyuncu [3] found that the contents of the main fatty acids of walnut genotypes were $5.24-7.62 \%$ palmitic, $2.56-3.67 \%$ stearic, $21.18-40.20 \%$ oleic, $43.94-60.12 \%$ linoleic and 6.91-11.52\% linolenic. Zwarts et al. [8] reported as $6.7-8.2 \%$ palmitic, $1.4-2.5 \%$ stearic, $13.8-33.0 \%$ oleic, 49.3-62.3\% linoleic and 8.0-14.2\% linolenic acids. The oleic acid content of walnut oil was lower than that of walnut oil reported by Zwarts et al. [8], Özkan and Koyuncu [3] and Koyuncu and Aşkın [22]. The walnut fatty acid composition shows high contents of linoleic acid and linolenic acid which are beneficial to human health and linoleic acid and especially linoleinic acid play important roles for human health regarding the cardio vascular system $[3,4,22]$.

The mineral contents of walnut kernels were determined by ICP-AES. The mineral compositions of kernels were summarized in Table 3. Mineral elements were found to vary widely depending on different walnut cultivar kernels. According to variance analyses, differences between walnut cultivars to $\mathrm{Ca}, \mathrm{Cu}, \mathrm{Fe}, \mathrm{K}, \mathrm{Mg}$, $\mathrm{Mn}, \mathrm{Na}$ and $\mathrm{P}$ were found statistically important at $\mathrm{p}<$ 0.01 level.
$\mathrm{Ca}, \mathrm{K}, \mathrm{Mg}, \mathrm{Na}$ and $\mathrm{P}$ contents of all the walnut cultivar kernels were generally found very high. In addition, other minerals were determined very low. The levels of Ca of samples ranged between $2462.3 \mathrm{mg} / \mathrm{Kg}$ (Büyükoba $\mathrm{cv}$ ) and $2757.9 \mathrm{mg} / \mathrm{Kg}$ (Kaman-5 cv), K contents were determined between $3478.8 \mathrm{mg} / \mathrm{Kg}$ (Büyükobacv) and $5476.2 \mathrm{mg} / \mathrm{Kg}$ (Kaman-5). While Mg contents are established between $4163.4 \mathrm{mg} / \mathrm{Kg}$ (Büyükoba cv) and 5488.1 $\mathrm{mg} / \mathrm{Kg}$ (Kaman-2 cv), P contents of kernels were found between $2226.2 \mathrm{mg} / \mathrm{Kg}$ (Büyükoba $\mathrm{cv}$ ) and 2604.3 $\mathrm{mg} / \mathrm{Kg}$ (Kaman-2 cv). Walnut kernels were found to be rich in some minerals such as Ca $(1108.6 \mathrm{mg} / \mathrm{kg}), \mathrm{K}$ (4627.6 mg/kg), P (3621.9 mg/kg), Na (44.7 mg/kg) Mn (46.3 mg/kg and $\mathrm{Mg}(1089.9 \mathrm{mg} / \mathrm{kg})$ [23]. Çağlarırmak [2] reported as 280-380 mg/100 g P, 230-340 mg/100 g $\mathrm{K}$, 81-99 mg/100 g Mg and 67-105.5 mg/100 g Ca in fresh walnut kernels. Our results were found differences compared with mineral values reported by Çağlarırmak [2]. These differencies of cultivars minerals may be due to growth conditions, varieties, genetic factors, harvesting time, soil properties, geographical variations and analytical procedures $[2,24]$. Calcium is the major component of bone and assists in teeth development [25]. Other elements which may contribute to biological processes, but which have not been established as essential are barium, cadmium [24]. The high quantity of potassium, phosphorus, magnesium, and calcium, together with the small proportion of sodium plus the content of

Table 3. Mineral contents of walnut kernels $(\mathrm{mg} / \mathrm{Kg})^{\mathrm{b}}$.

\begin{tabular}{|c|c|c|c|c|c|c|}
\hline \multirow{3}{*}{$\begin{array}{c}\text { Minerals } \\
\text { B }\end{array}$} & \multicolumn{6}{|c|}{ Walnut types } \\
\hline & \multicolumn{2}{|c|}{ Kaman-5 } & \multicolumn{2}{|c|}{ Büyük Oba } & \multicolumn{2}{|c|}{ Kaman-2 } \\
\hline & 15.114 & $\pm 1.503^{\mathrm{b}} \mathrm{C}$ & 11.985 & \pm 2.001 & 13.057 & $\pm 1.107 \mathrm{C}$ \\
\hline $\mathrm{Ca}$ & 2757.883 & $\pm 10.436 \mathrm{~B}$ & 2462.315 & $\pm 76.754 \mathrm{D}$ & 2637.618 & $\pm 37.460 \mathrm{~B}$ \\
\hline $\mathrm{Cr}$ & 1.695 & $\pm 0.360 \mathrm{C}$ & - & - & 3.323 & $\pm 2.820 \mathrm{C}$ \\
\hline $\mathrm{Cu}$ & 5.676 & $\pm 1.099 \mathrm{C}$ & 9.333 & $\pm 0.801 \mathrm{E}$ & 5.944 & $\pm 0.325 \mathrm{C}$ \\
\hline $\mathbf{F e}$ & 18.584 & $\pm 1.542 \mathrm{C}$ & 17.875 & $\pm 1.252 \mathrm{E}$ & 21.815 & $\pm 3.514 \mathrm{C}$ \\
\hline $\mathbf{K}$ & 5476.201 & $\pm 663.718 \mathrm{Aa}$ & 3478.757 & $\pm 482.96 \mathrm{Ab}$ & 5380.995 & $\pm 160.96 \mathrm{Aa}$ \\
\hline Mg & 4375.513 & $\pm 925.221 \mathrm{~A}$ & 4163.363 & $\pm 368.281 \mathrm{~B}$ & 5488.101 & $\pm 218.072 \mathrm{~A}$ \\
\hline Mn & 21.991 & $\pm 4.977 \mathrm{C}$ & 22.201 & $\pm 1.413 \mathrm{E}$ & 17.585 & $\pm 0.134 \mathrm{C}$ \\
\hline Mo & - & - & - & - & 1.671 & $\pm 0.537 \mathrm{C}$ \\
\hline $\mathrm{Na}$ & 617.713 & $\pm 65.545 \mathrm{C}$ & 667.416 & $\pm 74.322 \mathrm{D}$ & 833.433 & $\pm 26.601 \mathrm{C}$ \\
\hline $\mathrm{Ni}$ & 1.651 & $\pm 0.774 \mathrm{C}$ & - & - & 1.915 & $\pm 4.564 \mathrm{C}$ \\
\hline $\mathbf{P}$ & 2241.411 & $\pm 653.820 \mathrm{~B}$ & 2226.221 & $\pm 230.554 \mathrm{C}$ & 2604.255 & $\pm 45.318 \mathrm{~B}$ \\
\hline Zn & 17.981 & $\pm 0.523 \mathrm{C}$ & 20.623 & $\pm 1.185 \mathrm{E}$ & 18.353 & $\pm 4.206 \mathrm{C}$ \\
\hline
\end{tabular}

$\mathrm{a}^{\text {Dryweight, }}{ }^{\mathrm{b}}$ mean \pm standard deviation 
the essential elements as iron, manganese, copper, and zinc and allows the apricot, as well as the almond, to be considered as an excellent source of bioelements [26].

\section{CONCLUSIONS}

The accurate quantification of these analyses has very important applications for the nutrition sciences, because fatty acids, protein, oil and mineral contents in particular seed have a very important effect on health. These results of the experiment presented have shown that apricot cultivars have some distinctive chemical and physiccal properties, fatty acid and mineral content profiles. Kernels in apricot varieties can be good source oil due to their abundance in the kernels and their high oil content. Such utilization of apricot fruits processing wastes could provide extra income and at the same time help minimize a waste disposal problem. The mineral contents of apricot cultivar kernels collected from Malatya province of Turkey were established by ICP-AES. The contents of most minerals such as $\mathrm{Ca}, \mathrm{K}, \mathrm{Mg}$ and $\mathrm{P}$ are at adequate levels. Mineral elements were found to vary widely depending on different apricot kernels. Apricot kernels were found to be important sources of nutrients and essential elements. In addition, it is apparent that apricot kernels are good sources of micro and macro minerals, and consumed as a food ingredient to provide the human nutrient.

In this study, Kaman walnut varieties have got standard walnut properties. When these varieties were grown modified conditions, it was estimated to be having more quality. While walnuts have about $13.2 \mathrm{~g}$ fruit weight, 38 $\mathrm{mm}$ diameter with hull, $6.5 \mathrm{~g}$ hull weight, $7 \mathrm{~g}$ kernel weight, $55 \%$ yield due to physical properties, as a chemical properties walnut contained $98 \%$ dry matter, $65 \%$ crude oil, $2 \%$ ash, $7.4 \%$ crude protein and $3.75 \%$ crude fiber. The oils of walnut varieties are more yellowish-clear. Mean peroxide value, free fatty acidity, density, saponification value, refractive index values are $3.2 \mathrm{meq} / \mathrm{kg}, 0.4 \%, 13.9 \mathrm{~g} / \mathrm{ml}, 107.5,1.535 \mathrm{n}_{\mathrm{D}}$, respecttively. The major fatty acids of walnut oils were established as $6.4 \%$ palmitic, $2.5 \%$ stearic, $23 \%$ oleic, $51.5 \%$ linoleic and $14.4 \%$ linolenic. The highest minerals were $\mathrm{Ca}, \mathrm{Mg}, \mathrm{K}$ and $\mathrm{P}$. Walnut is one of important foods need found in daily diets. High polyunsaturated fatty acid contents are the most important properties. At the same time, due to walnut's nutrition important was thought to be found between strategic foods in future.

\section{ACKNOWLEDGEMENTS}

This work was supported by Selçuk University Scientific Research
Project (S.U.-BAP. Konya-Turkey)

\section{REFERENCES}

[1] Şen, S.M. (1986) Ceviz Yetiştiriciliği. Eser Matbaası, Samsun.

[2] Çağlarırmak, N. (2003) Biochemical and physical properties of some walnut genotypes (Juglans regia L.). Nahrung/Food, 47(1), 28-32.

[3] Özkan, G. and Koyuncu, M.A. (2005) Physical and chemical comparision of some walnut (Juglans regia L.) genotypes grown in Turkey. Grasas y Aceites 56(2), 142-147.

[4] Sabate, J., Fraser, G.E., Burke, K., Knutsen, S.F., Benett, H., Linstead, K.D. (1993) Effects of walnuts on serum lipid levels and blood pressure in normal men. The New England Journal of Medicine, 328(9), 603-607.

[5] Savage, G.P. (2001) Chemical composition of walnuts (Juglans regia L.) grown in New Zealand. Plant Foods for Human Nutrition, 56(1), 75-82.

[6] Olez, H. (1971) Marmara bölgesi cevizlerinin (Juglans regia L.) seleksiyon yoluyla ıslahı üzerine araştırmalar. Yalova Bahçe Kültürleri Araştırma Merkezi Dergisi, 4(8), 1-4.

[7] Beyhan, O.E., Kaya, I., Şen, S.M. Doğan, M. (1995) Fatty acid composition of walnut (Juglans regia L.) types selected in Darende. Turkish Journal of Agricultural Forestry 19(4), 299-302.

[8] Zwarts, L., Savage, G.P. and McNeil, B.L. (1999) Fatty acid content of New Zealand-grown walnuts (Juglans regia L.). International Journal of Food Science Nutrition, 50(3), 189-194.

[9] Greve, C., Mc Granahan, G., Hasey, J., Synder, R., Kelly, K., Gold, H. D. and Labavitch, J. (1992) Variationin polyunsaturated fatty acids composition of Persian walnut. Journal of American Social Hart Science, 117(3), 518-522.

[10] Helmy, H.E. (1990) Studies on the pigments of some citrus, prune and cucurbit seed oils when processed with or without cottonseed oil. Journal of American Oil Chemist Society, 67(6), 376-380.

[11] Association of Official Analytical Chemists (1984) Official Methods of Analysis. Association of Official Chemistry, 14th Edition, Arlington.

[12] Hış1l, Y. (1998) Instrumental Analysis Techniques. Ege University Engineering Faculty Publication, Bornovaİzmir.

[13] AOCS. (1990) Official Methods and Recommended Practices. 4th Edition, American Oil Chemists Society, Champaign. II.

[14] Skujins, S. (1998) Handbook for ICP-AES (Varian-Vista). A short Guide to Vista Series. ICP-AES Operation. VarianInt. AG. Zug. Version 1.0., Switzerland.

[15] Püskülcü, H. and İkiz, F. (1989) Introduction Statistic (İstatistiğe Giriş). Bilgehan Press. Bornova-İzmir.

[16] Garcia, J.M., Agar, I.I. and Streit, J. (1994) Lipid characterijation in kerrels from different walnut cultivars. Turkish Journal of Agricultural Forestry, 18, 195-198.

[17] Gunstore, F.D. and Norris, F.A. (1983) Lipids in Foods: Chemistry. Biochemistry and Technology, 1st Edition, Oxford. 
[18] Colombini, M., Vanoni, M.C. and Amelotti, G. (1979) Olio di noci. nocciole. mandorle. avocado: Composizione sterolica. La Rivista Italiana delle Sostanze Grasse, 56, 392-393.

[19] Allam, S.S.H. (2001) Utilization of some untraditional sources of high oleic acid oils for improving vegetable oils stability. La Rivista Italiana Delle Sostanze Grasse 78(6), 337-341.

[20] Yücel, S.O. (2005) Determination of conjugated linolenic acid content of selected oil seeds grown in Turkey. Journal of American Oil Chemist Society, 82(12), 893-897.

[21] Koyuncu, M. and Aşkın, M.A. (1999) Van Gölü çevresinde yetiștiriciliği yapılan bazı ceviz tiplerinin depolanması üzerine çalışmalar. Turkish Journal of Agricultural Forestry, 23(4), 785-796.

[22] Abbey, M., Noaks, M., Belling, G.B. and Nestel, P.J. (1994) Partial replacement of saturated fatty acids with almonds or walnuts lowers total plasma cholesterol and low-density lipoprotein cholesterol. American Journal Clinical Nutrition, 59(5), 995-999.

[23] Özcan, M. (2009) Some proximate characteristics of fruit and oil of walnut (Juglans regia L.) growing in Turkey. Iranian Journal of Chemistry \& Chemical Engineering 28(1), 7-62.

[24] Macrae. R., Robinson, R.K. and Sadler, M.J. (Eds.), (1993) Encyclopaedia of Food Science. Food Technology and Nutrition, Academic Press INC, San Diego, 31263131.

[25] Brody, T. (1994) Nutritional Biochemistry. Academic Press, San Diego.

[26] Saura-Calixto, F. and Canellas, J. (1982) Correlations between lipid and protein contents in nuts and oil seeds. Anal Bromatol, 34, 23-31. 